\title{
Size-dependent and shape-dependent algal toxicity of Aluminum oxide nanoparticles
}

\author{
Wenting Ren, Ruifeng Hou, Shuang Yin, Huan Yao, Xuesong Cao \\ ${ }^{1}$ College of Environmental Science and Engineering, Ocean University of China, Qingdao 266100, \\ China
}

Keywords: $\mathrm{Al}_{2} \mathrm{O}_{3}$ nanoparticles, shape, size, toxicity, electrostatic interaction

\begin{abstract}
In this work, we investigated the toxicity of $\mathrm{Al}_{2} \mathrm{O}_{3}$ particles with different size and shape to algae (Chlorella pyenoidosa). It was indicated that the toxicity of $\mathrm{Al}_{2} \mathrm{O}_{3}$ nanoparticles (NPs) was the strongest and the toxicity caused by bulk particles (BPs) was weaker than that of $\mathrm{Al}_{2} \mathrm{O}_{3} \mathrm{NPs}_{\text {. }}$ $\mathrm{Al}_{2} \mathrm{O}_{3}$ Fiber exhibited weakest toxicity to algae. Electrostatic interaction-induced physical contact could be a major mechanism to explain the difference of the observed toxicity.
\end{abstract}

\section{Introduction}

$\mathrm{Al}_{2} \mathrm{O}_{3}$ nanoparticles (NPs) are widely used in commercial applications such as explosive combinations, ceramics, catalyst and composite materials ${ }^{[1]}$. With the rapid increases in production and application, $\mathrm{Al}_{2} \mathrm{O}_{3}$ NPs will be released into aquatic environment. Upon exposure, they will exhibit adverse impacts on organisms. Sadiq et al. (2011) reported that $\mathrm{Al}_{2} \mathrm{O}_{3} \mathrm{NPs}$ can inhibit the growth of Scenedesmus sp. and Chlorella $s p$. The $\mathrm{EC}_{50}$ of Scenedesmus sp. is higher than that of Chlorella sp. and the entrapment ability of algal cells to $\mathrm{Al}_{2} \mathrm{O}_{3}$ played an important role ${ }^{[2]}$. Jacqueline et al. (2009) have used $0.7 \mu \mathrm{m} \mathrm{Al}_{2} \mathrm{O}_{3}$ and $1.6 \mu \mathrm{m} \mathrm{SiO}_{2}$ to assess the cellular uptake and cellular toxicity of lunar dust particle analogs. According to the results, two type of cells showed minimal cytotoxicity exposure to $\mathrm{Al}_{2} \mathrm{O}_{3}{ }^{[3]}$. Wang et al. (2009) characterized the toxicity and behavior of nanoparticles and bulk metal oxide $\mathrm{ZnO}, \mathrm{Al}_{2} \mathrm{O}_{3}$ and $\mathrm{TiO}_{2}$ to C.elegans in an aqueous medium. The results indicated that $\mathrm{Al}_{2} \mathrm{O}_{3}$ NPs induced the weakest toxicity among the three type of metal NPs and the toxicity caused by $\mathrm{Al}_{2} \mathrm{O}_{3}$ NPs is stronger than that of bulk particles (BPs) ${ }^{[4]}$. In the natural environment, the morphologies of $\mathrm{Al}_{2} \mathrm{O}_{3}$ particles are various and may occur a series of interaction. Ren et al. (2014) reported that $\mathrm{Al}_{2} \mathrm{O}_{3}$ could heteroaggregate with graphene oxide, altering the environment fate and biovailability of graphene oxide ${ }^{[5]}$. Many articles had reported that the shape and size factors had a great effect on the toxicity of nanoparticles. Leanne et al. (2016) revealed that compared to $\mathrm{CuO}$ nanospheres, $\mathrm{CuO}$ nanosheet had higher surface reactivity and bacterial toxicity ${ }^{[6]}$. Pan et al. (2009) reported that 1-2 nm Au NPs reduced the most toxicity among all the $0.8-15 \mathrm{~nm} \mathrm{Au} \mathrm{NPs}{ }^{[7]}$. So, it is important to investigate the toxicity of $\mathrm{Al}_{2} \mathrm{O}_{3}$ with different morphologies on freshwater algae. Therefore, in the study, $\mathrm{Al}_{2} \mathrm{O}_{3}$ particles with different size and shape were chosen to research the toxicity on Chlorella pyenoidosa.

\section{Materials and Method}

2.1 Exposure Experiment. The three types of $\mathrm{Al}_{2} \mathrm{O}_{3}$ particles $\left(\mathrm{Al}_{2} \mathrm{O}_{3} \mathrm{NPs}, \mathrm{Al}_{2} \mathrm{O}_{3} \mathrm{BPs}\right.$ and $\mathrm{Al}_{2} \mathrm{O}_{3}$ Fiber) were purchased from Nanjing XFNANO (China). The Chlorella pyrenoidesa was purchased from the institute of Hydrobiology, Chinese Academy of Science, China. In our study, the modified SE medium (one-tenth SE medium) was used for algal cells culture medium, in which the nutrient was sufficient for algal growth. The $\mathrm{pH}$ of culture medium was adjusted to 7.0 by adding negligible amounts of $\mathrm{NaOH}$ or $\mathrm{HCl}$. The algal cells were grown under the light intensity of 12000 lux (14: 10 light: dark cycle) in a light growth chamber (GXZ, China) at $24^{\circ} \mathrm{C}$. For algal growth inhibition assay, algal cells $\left(1 \times 10^{6}\right.$ cells/mL $)$ were cultured two days to achieve the exponential growth phase. $\mathrm{Al}_{2} \mathrm{O}_{3}$ were pre-suspended in algal medium and then added to exponentially growing algal cells to reach the final concentrations. The algal suspensions were shaken twice every day and the algal cells were counted under a light microscope (JNOEC, China) after two days. 
2.2 Statistical Analysis. The inhibition rate of $\mathrm{Al}_{2} \mathrm{O}_{3}$ particles was calculated by the equation as follows:

Inhibition Rate $(\%)=\left(1-\mathrm{A} / \mathrm{A}_{0}\right) * 100 \%$

A: the algae cells concentration of treatment group

$\mathrm{A}_{0}$ : the algae cells concentration of control group

The median effective concentration $\left(\mathrm{EC}_{50}\right)$ was calculated by nonliear regression using the cumulative distribution function of SPSS Statistics. All data included three replicates and standard error was statistically analyzed $(\mathrm{p}<0.05)$.

\section{Results and Discussion}

3.1 Characterization of different types of $\mathbf{A l}_{2} \mathbf{O}_{3}$. Characterization of $\mathrm{Al}_{2} \mathrm{O}_{3}$ particles was analyzed by transmission electron microscopy (TEM, H-7650, Hitachi, Japan). The TEM images showed that the size of $\mathrm{Al}_{2} \mathrm{O}_{3}$ NPs was 8-12 nm (Fig. 1A). The size of $\mathrm{Al}_{2} \mathrm{O}_{3}$ BPs was 100-300 nm (Fig. 1B). The length of $\mathrm{Al}_{2} \mathrm{O}_{3}$ Fiber was $100-200 \mathrm{~nm}$ and the width was 8-10 nm (Fig. 1C). Different with $\mathrm{Al}_{2} \mathrm{O}_{3}$ BPs and $\mathrm{Al}_{2} \mathrm{O}_{3}$ Fiber, $\mathrm{Al}_{2} \mathrm{O}_{3}$ NPs formed the biggest homoaggregate. It was possibly attributed to the huge surface area of $\mathrm{Al}_{2} \mathrm{O}_{3}$ NPs.
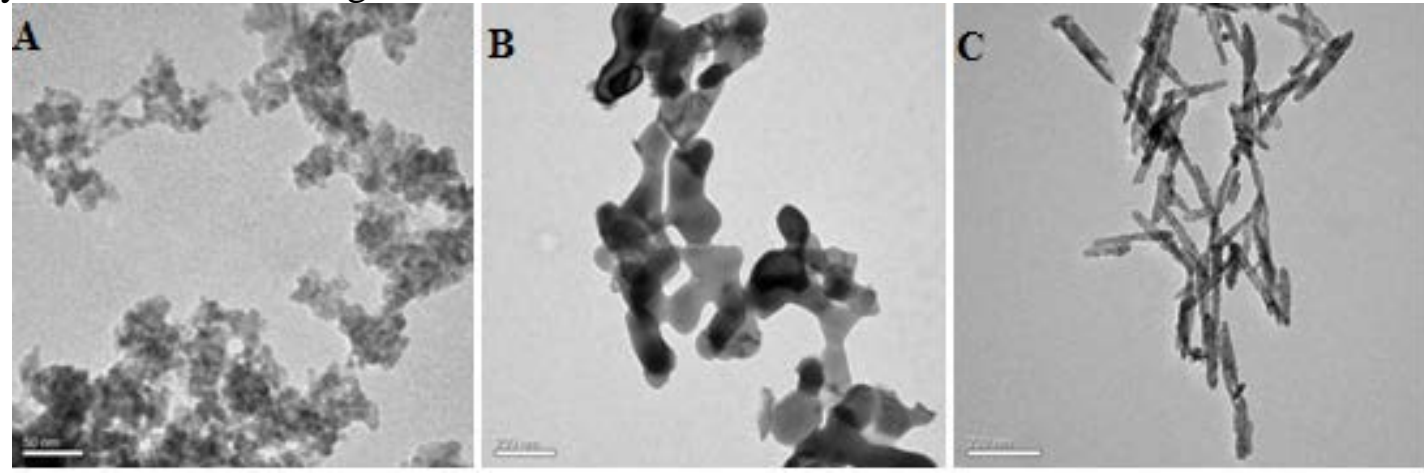

Fig. 1 TEM images of $\mathrm{Al}_{2} \mathrm{O}_{3}$ particles. (A) $\mathrm{Al}_{2} \mathrm{O}_{3}$ NPs, the ruler line is $50 \mathrm{~nm}$; (B) $\mathrm{Al}_{2} \mathrm{O}_{3} \mathrm{BPs}$, the ruler line is $200 \mathrm{~nm}$; (C) $\mathrm{Al}_{2} \mathrm{O}_{3}$ Fiber, the ruler line is $200 \mathrm{~nm}$.

At $\mathrm{pH}$ 7.0, the zeta potentials of $\mathrm{Al}_{2} \mathrm{O}_{3}$ and algae were measured by Zetasizer (Nano ZS90, Malvern, UK) and showed in Table 1. The zeta potentials of $\mathrm{Al}_{2} \mathrm{O}_{3} \mathrm{NPs}, \mathrm{Al}_{2} \mathrm{O}_{3}$ BPs and $\mathrm{Al}_{2} \mathrm{O}_{3}$ Fiber were $35.04 \mathrm{mV}, 28.87 \mathrm{mV}$ and $19.16 \mathrm{mV}$, respectively. However, algae cells were highly negatively charged.

\begin{tabular}{ccccc}
\multicolumn{5}{c}{ Table 1 The zeta potential of $\mathrm{Al}_{2} \mathrm{O}_{3}$ particles and algae at $\mathrm{pH} 7.0$} \\
\hline Type & $\mathrm{Al}_{2} \mathrm{O}_{3} \mathrm{NPs}$ & $\mathrm{Al}_{2} \mathrm{O}_{3} \mathrm{BPs}$ & $\mathrm{Al}_{2} \mathrm{O}_{3}$ Fiber & algae \\
& & & & \\
\hline Zeta potential $(\mathrm{mV})$ & $35.04 \pm 3.56$ & $28.87 \pm 0.87$ & $19.16 \pm 0.48$ & $-33.43 \pm 0.65$ \\
\hline
\end{tabular}

3.2 The toxicity of $\mathbf{A l}_{2} \mathrm{O}_{3}$ particles. Fig. 2 showed the toxicity of $\mathrm{Al}_{2} \mathrm{O}_{3}$ particles on $48 \mathrm{~h} . \mathrm{Al}_{2} \mathrm{O}_{3}$ NPs had the strongest toxicity among the three type of $\mathrm{Al}_{2} \mathrm{O}_{3}$ particles, while the toxicity of $\mathrm{Al}_{2} \mathrm{O}_{3}$ Fiber was weakest. The $\mathrm{EC}_{50}$ of $\mathrm{Al}_{2} \mathrm{O}_{3} \mathrm{NPs}, \mathrm{Al}_{2} \mathrm{O}_{3} \mathrm{BPs}$ and $\mathrm{Al}_{2} \mathrm{O}_{3}$ Fiber were $64.57 \mathrm{mg} / \mathrm{L}, 95.50$ $\mathrm{mg} / \mathrm{L}, 147.91 \mathrm{mg} / \mathrm{L}$, respectively. The order of toxicity was completely same with that of zeta potential. The three types of $\mathrm{Al}_{2} \mathrm{O}_{3}$ particles were both positive charged at $\mathrm{pH} 7.0$, while algae was highly negatively charged. Zhao et al. (2015) reported that GO with negatively charged and goethite with positive charged could happen heteroaggregation ${ }^{[8]}$. Heteroaggregation may occur between $\mathrm{Al}_{2} \mathrm{O}_{3}$ and algae, too. So we assume heteroaggregation caused by electrostatic interaction may be a major reason to explain the toxicity of $\mathrm{Al}_{2} \mathrm{O}_{3}$ particles. 


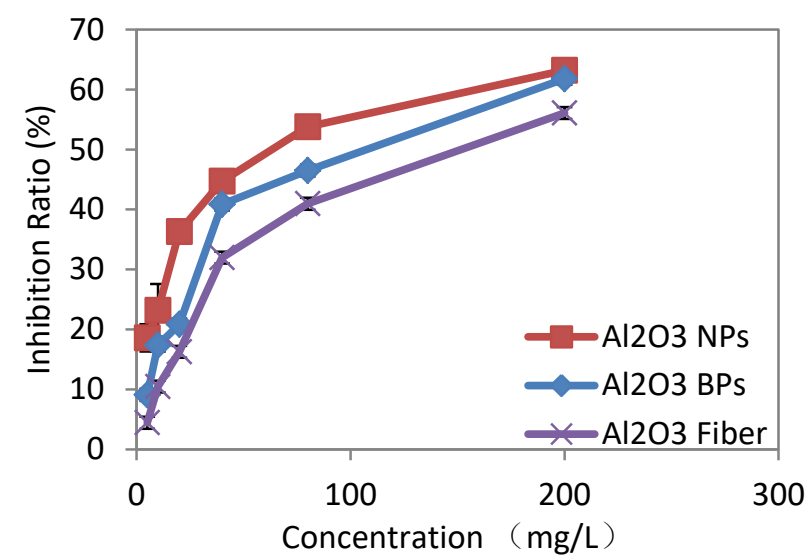

Fig. 2 The toxicity of $\mathrm{Al}_{2} \mathrm{O}_{3}$ particles to algal cells on $48 \mathrm{~h}$. The red, blue and purple column indicated respectively the toxicity of $\mathrm{Al}_{2} \mathrm{O}_{3} \mathrm{NPs}, \mathrm{Al}_{2} \mathrm{O}_{3}$ BPs and $\mathrm{Al}_{2} \mathrm{O}_{3}$ Fiber. Error bars indicated one standard deviation of at least three measurements.

\section{Conclusion}

$\mathrm{Al}_{2} \mathrm{O}_{3}$ particles were toxic to algae. Among the three types of $\mathrm{Al}_{2} \mathrm{O}_{3}$ particles, $\mathrm{Al}_{2} \mathrm{O}_{3} \mathrm{NPs}$ showed the strongest toxicity, while, the toxicity of $\mathrm{Al}_{2} \mathrm{O}_{3}$ Fiber was weakest. Electrostatic interaction-induced physical contact could be a major mechanism for the toxicity.

\section{Acknowledgments}

This research was supported by Natural science Foundation of China (41573092, 41530642).

\section{References}

[1] Pamela J, Kaste B. Novel energetic materials for the future force: The army pursues the next generation of propellants and explosives. The Amptiac Newsletter, 2004, 8(4): 85-89.

[2] Sadiq I M, Pakrashi S, Chandrasekaran N, et al. Studies on toxicity of aluminum oxide $\left(\mathrm{Al}_{2} \mathrm{O}_{3}\right)$ nanoparticles to microalgae species: Scenedesmus sp. and Chlorella sp. Journal of Nanoparticle Research, 2011, 13(8): 3287-3299.

[3] Jordan J A, Verhoff A M, Morgan J E, et al. Assessing the in vitro toxicity of the lunar dust environment using respiratory cells exposed to $\mathrm{Al}_{2} \mathrm{O}_{3}$ or $\mathrm{SiO}_{2}$ fine dust particles. In Vitro Cellular \& Developmental Biology-Animal, 2009, 45(10): 602-613.

[4] Wang $\mathrm{H}$, Wick R L, Xing B. Toxicity of nanoparticulate and bulk $\mathrm{ZnO}, \mathrm{Al}_{2} \mathrm{O}_{3}$ and $\mathrm{TiO}_{2}$ to the nematode Caenorhabditis elegans. Environmental Pollution, 2009, 157(4): 1171-1177.

[5] Ren X, Li J, Tan X, et al. Impact of $\mathrm{Al}_{2} \mathrm{O}_{3}$ on the aggregation and deposition of graphene oxide. Environmental science \& technology, 2014, 48(10): 5493-5500.

[6] Gilbertson L M, Albalghiti E M, Fishman Z S, et al. Shape-dependent surface reactivity and antimicrobial activity of nano-cupric oxide. Environmental science \& technology, 2016, 50(7): 3975-3984.

[7] Pan Y, Leifert A, Ruau D, et al. Gold nanoparticles of diameter $1.4 \mathrm{~nm}$ trigger necrosis by oxidative stress and mitochondrial damage. Small, 2009, 5(18): 2067-2076.

[8] Zhao J, Liu F, Wang Z, et al. Heteroaggregation of graphene oxide with minerals in aqueous phase. Environmental science \& technology, 2015, 49(5): 2849-2857. 